\title{
EXPLOITABLE GENETIC VARIABILITY AND DETERMINATION OF SELECTION CRITERIA USING PATH COEFFICIENT ANALYSIS IN CHICKPEA
}

\author{
Indu BaLA, RAMa Kalia*and Bhupender Kumar ${ }^{1}$ \\ Molecular Cytogenetics and Tissue Culture Laboratory, Department of Crop Improvement, \\ CSK Himachal Pradesh Agricultural University, Palampur-176 062, India
}

Key words: Cicer arietinum, Genetic variability, Correlation, Path coefficient, Seed yield

\begin{abstract}
This study estimates the nature and extent of genetic variability as well as direct and indirect effects of yield related traits on seed yield in 25 chickpea genotypes. The pooled analysis of variance over the environments indicated significant genotypes effect compared to genotype $(g) \times$ environment (e) interactions for all the characters. The mean values of the characters studied showed a wide spectrum of genetic variation. The genotypes ICCV 96904 and Himachal Chana-1 were found to be promising for seed yield and biological yield per plant in pooled over the environments. The phenotypic correlation coefficient revealed significant positive associations of pods per plant, harvest index, biological yield per plant and primary branches per plant with seed yield per plant. The path coefficient analysis revealed that biological yield per plant and harvest index exhibited positive and high direct effects on seed yield per plant. Therefore, these characters could be considered as the best selection parameters for the improvement of seed yield per plant.
\end{abstract}

Chickpea (Cicer arietinum L. Fam: Fabaceae) is one of the world's most important but lessstudied leguminous food crop with 740-Mb genome size. Chickpea with $17-24 \%$ protein, $41-51 \%$ carbohydrates and high content of other nutrients, is one of the most important food legumes in the world. Chickpea is an important pulse crop of rabi season of India. Its productivity has remained almost constant due to lack of high yielding genotypes with stable performance over the environments.

The success in any breeding programme depends upon the nature and magnitude of genetic variability which provides better chances of selecting desired plant types. The knowledge of interrelationships between different traits is important in breeding for direct and indirect selection of characters that are not easily measured and has low heritability. Some of the characters are highly associated among themselves and with seed yield. The analysis of the relationships among these characters and their associations with seed yield is essential to establish selection criteria. However, simple correlation coefficients between yield and yield components may not give satisfactory results, this is because, the components do not only affect the yield directly, but they may also affect it indirectly by affecting other yield components in negative or positive direction. Under such situations, the path coefficient analysis helps to determine the direct or indirect contribution of these characters for final seed yield in plant (Singh et al. 1990). So the present study was conducted to investigate the extent of genetic variability, association of seed yield with other component characters and to estimate the direct and indirect effects of various characters on seed yield in chickpea.

An experiment was conducted with 25 chickpea genotypes including a few North-West Himalayan lines at the experimental farm of the Department of Crop Improvement, CSK HPKV, Palampur. The trials were laid out in randomized complete block design with three replications in

*Author for correspondence: <rama.cskhpkv@gmail.com>. ${ }^{1}$ Cummings’s Lab., Directorate of Maize Research, Pusa Campus New Delhi-12, India. 
the plot sizes of $2.5 \times 0.9 \mathrm{~m}^{2}$ during rabi 2008 and 2009. Row to row and plant to plant spacing were kept 30 and $10 \mathrm{~cm}$, respectively. The observations were recorded for different morpho-metric and yield related characters viz., days to $50 \%$ flowering, days to maturity, plant height, primary branches per plant, biological yield per plant, pods per plant, seed yield per plant, harvest index, 100 -seed weight and per cent crude protein.

For morpho-metric and yield related characters, observations were recorded on the basis of ten randomly competitive plants in each plot except, days to $50 \%$ flowering and days to maturity which were recorded on plot basis.

The analysis of variance for different characters was carried out by following Panse and Sukhatme (1985) approach. The estimation of parameters of variability were calculated as per the methods suggested by Burton and De Vane (1953) and Johnson et al. (1955). Correlation coefficients at phenotypic levels were computed as per the methods suggested by Al-Jibouri et al. (1958) and path coefficient analysis was done by using correlation coefficients as suggested by Dewey and Lu (1959).

The pooled analysis over the environments, exhibited that mean squares due to genotypes were significant when tested against mean squares due to $\mathrm{g} \times \mathrm{e}$ interactions for all the characters studied. Significant mean squares due to $\mathrm{g} \times \mathrm{e}$ interaction for seed yield and its related traits has also been reported by Dehghani et al. (2010). Significant variation for most of the characters viz., number of primary branches, number of pods per plant, 100-seed weight, biological yield per plant, harvest index and seed yield per plant was also observed by Sharma and Saini (2010).

The mean values of the characters studied showed a wide spectrum of genetic variation and characters such as days to $50 \%$ flowering, pods per plants, 100 -seed weight, seed yield per plant, biological yield per plant, harvest index and crude protein recorded excellent potential on the basis of mean performance. ICCV 96904 and Himachal Chana-1 were found to be promising genotypes for seed yield and biological yield per plant.

Table 1. Estimates of parameters of variability among different traits (pooled over the environments).

\begin{tabular}{llccccc}
\hline Traits & Range & $\begin{array}{c}\text { PCV } \\
(\%)\end{array}$ & $\begin{array}{c}\text { GCV } \\
(\%)\end{array}$ & $\begin{array}{c}\text { ECV } \\
(\%)\end{array}$ & $\begin{array}{c}\text { h}^{2} \text { bs } \\
(\%)\end{array}$ & $\begin{array}{c}\text { Genetic } \\
\text { advance (\%) } \\
\text { of mean }\end{array}$ \\
\hline Days to 50\% flowering & $97.83-112.83$ & 4.32 & 3.12 & 2.99 & 52.25 & 4.65 \\
Days to maturity & $192.34-205.34$ & 2.16 & 1.17 & 1.82 & 29.35 & 1.31 \\
Plant height (cm) & $60.71-79.00$ & 11.24 & 4.35 & 10.36 & 14.97 & 3.46 \\
Primary branches per plant & $7.26-12.43$ & 19.72 & 10.27 & 16.83 & 27.16 & 11.03 \\
Biological yield per plant (g) & $150.00-218.34$ & 17.96 & 8.62 & 15.75 & 23.06 & 8.53 \\
Pods per plant & $32.60-66.03$ & 26.27 & 15.63 & 21.12 & 35.40 & 19.16 \\
Seed yield per plant (g) & $39.16-84.16$ & 27.75 & 16.44 & 22.36 & 35.09 & 20.06 \\
Harvest index (\%) & $24.91-40.45$ & 20.71 & 10.82 & 17.66 & 27.29 & 11.64 \\
100-seed weight (g) & $14.41-24.58$ & 17.00 & 15.05 & 7.90 & 78.40 & 27.45 \\
Protein content (\%) & $19.49-22.31$ & 5.21 & 3.44 & 3.91 & 43.59 & 4.68 \\
\hline
\end{tabular}

PCV: Phenotypic coefficient of variation; GCV: Genotypic coefficient of variation. ECV: Environmental coefficient of variation; $h^{2}$ bs: Heritability in broad sense. GA: Genetic advance (\%) of mean

Maximum range was found for biological yield per plant followed by seed yield per plant and pods per plant indicating wide range of genetic variability (Table 1). The PCV and GCV are the indicators of observed and genetic variability. Similar findings with respect to PCV and GCV have been reported by Deshmukh et al. (2004). The PCV and GCV are of little importance if some other parameters like heritability and genetic advance are not calculated, because of their difficult 
characterization for comparison of populations with desired precision when expressed in absolute values.

The information on heritability estimates is useful in studying the inheritance of quantitative traits as well as for planning breeding programmes with desired degree of expected genetic progress. The present study revealed that heritability in broad sense was high $(>70 \%)$ for 100 -seed weight. High heritability estimates for most of the traits studied have also been reported earlier by Maloo and Sharma (1990). The response to selection for different traits which showed high heritability need to be given due emphasis for effective selection and suggested that these traits were under genetic control. However, the high heritability does not necessarily mean high genetic gain and alone is not sufficient to make improvement through selection. Thus, the genetic advance has an added edge over heritability as a guiding factor to breeders in various selection programmes. Based on this consideration, high heritability coupled with high genetic advance was observed for pods per plant, seed yield per plant and 100-seed weight. It indicated predominance of additive gene action in the inheritance of these traits and selection would be most effective.

At phenotypic level, seed yield per plant had significant positive association with pods per plant, harvest index, biological yield per plant and primary branches per plant. Positive association of seed yield per plant with primary branches per plant, biological yield per plant, pods per plant and harvest index was also observed by Biabani et al. (2011).

The path coefficient analysis revealed that at phenotypic level, the high positive direct effects on seed yield could be contributed by biological yield per plant and harvest index (Table 2). The results are in conformity with earlier findings (Zali et al. 2011). Selection on the basis of biological yield per plant and harvest index will result into higher seed yield per plant. Residual effect (0.282) recorded in present investigation indicated that the characters studied accounted for much of the variation for seed yield per plant.

Finally, it is concluded that existence of considerable genetic variation among the genotypes, which may help in designing the selection methodology to be used further in the breeding programme for seed yield improvement in chickpea.

\section{References}

Al-Jibouri HA, Millar PA and Robinson HF 1958. Genotypic and environmental variances and covariances in an upland cotton cross of interspecific origin. Agron. J. 50: 633-636.

Biabani A, Katozi M, Mollashahi M, Bahlake AG and Khani AHG 2011. Correlation and relationships between seed yield and other characteristics in chickpea (Cicer arietinum L.) cultivars under deterioration. Africa. J. Agric. Res. 6: 1359-1362.

Burton G and De Vane EH 1953. Estimating heritability in tall fescue (Festuca arundinacea) from replicated clonal material. Agron. J. 45: 478-481.

Dewey DR and Lu KH 1959. A correlation and path coefficient analysis of components of crested wheat grass seed production. Agron. J. 51: 515-518.

Deshmukh DV, Mhase LB and Jamadagni BM 2004. Evaluation of chickpea genotypes for drought tolerance. Indian J. Pulses Res. 17: 47-49.

Dehghani H, Hossain S, Sabaghpour and Ebadi A 2010. Study of Genotype x Environment interaction for chickpea yield in Iran. Agron. J. 102: 1-8.

Johnson HW, Robinson HF and Comstock RE 1955. Estimates of genetic and environmental variability in soybeans. Agron. J. 47: 314-318.

Maloo SR and Sharma PP 1990. Variability studies for biometrical traits in gram. Madras Agric. J. 77: 576578.

Panse VG and Sukhatme PV 1985. Statistical methods for agricultural workers. Indian Council of Agricultural Research, New Delhi. p 359. 
Sharma LK and Saini DP 2010. Variability and association studies for seed yield and yield components in chickpea (Cicer arietinum L.). Res. J. Agric. Sci. 1: 209-211.

Singh KB, Bejiga G and Malhotra R 1990. Associations of some characters with seed yield in chickpea collections. Euphytica 49: 83-88.

Zali H, Farshadfar E and Sabaghpour SH 2011. Genetic variability and interrelationships among agronomic traits in chickpea (Cicer arietinum L.) genotypes. Crop Breed. J. 1: 127-1

(Manuscript received on 10 April, 2013; revised on 15 July, 2014) 